\title{
Compatibility Choice by Multi-market Firms
}

\author{
Citation for published version (APA):
}

van Wegberg, M. J. (2004). Compatibility Choice by Multi-market Firms. Information Economics and Policy, 16(2), 235-254. https://doi.org/10.1016/j.infoecopol.2003.09.011

Document status and date:

Published: 01/01/2004

DOI:

10.1016/j.infoecopol.2003.09.011

Document Version:

Publisher's PDF, also known as Version of record

\section{Please check the document version of this publication:}

- A submitted manuscript is the version of the article upon submission and before peer-review. There can be important differences between the submitted version and the official published version of record.

People interested in the research are advised to contact the author for the final version of the publication, or visit the DOI to the publisher's website.

- The final author version and the galley proof are versions of the publication after peer review.

- The final published version features the final layout of the paper including the volume, issue and page numbers.

Link to publication

\footnotetext{
General rights rights.

- You may freely distribute the URL identifying the publication in the public portal. please follow below link for the End User Agreement:

www.umlib.nl/taverne-license

Take down policy

If you believe that this document breaches copyright please contact us at:

repository@maastrichtuniversity.nl

providing details and we will investigate your claim.
}

Copyright and moral rights for the publications made accessible in the public portal are retained by the authors and/or other copyright owners and it is a condition of accessing publications that users recognise and abide by the legal requirements associated with these

- Users may download and print one copy of any publication from the public portal for the purpose of private study or research.

- You may not further distribute the material or use it for any profit-making activity or commercial gain

If the publication is distributed under the terms of Article $25 \mathrm{fa}$ of the Dutch Copyright Act, indicated by the "Taverne" license above, 


\title{
Compatibility choice by multi-market firms
}

\author{
Marc van Wegberg * \\ Faculty of Economics and Business Administration, University of Maastricht, P.O. Box 616, \\ 6200 MD Maastricht, The Netherlands
}

Available online 21 October 2003

\begin{abstract}
There are many markets where customers can combine multiple products to greater effect, or where customers can communicate with each other. In these cases compatibility of products by different vendors has a large effect on the product market. Which choice firms make about the compatibility of their products tends to depend on the wider context in which they make this choice. Some vendors may be multi-product or multi-market forms. The implications that (in)compatibility in one market may have for their other markets will affect their compatibility choice. A corollary of this argument is that a change in the multi-product or multi-market scope of a firm will create a strategic shift in its preference for compatibility. Both mergers and alliances may have the effect of changing the relevant scope of products or product markets that a firm serves. The event of such a merger or alliance will tend to change its compatibility preference. This paper develops a model to explain the possible strategy shift of a merger or alliance due to feedback between the various markets that a firm serves. It explores the compatibility choices for digital videodisks that consumer electronics, computer, and media companies experienced in the mid-1990s.
\end{abstract}

(C) 2003 Elsevier B.V. All rights reserved.

JEL classification: L13; L86; L96; G34

Keywords: Compatibility choice; Multi-market scope; Alliance; Merger

\footnotetext{
${ }^{*}$ Tel.: +31-43-3883654; fax: +31-43-3884893.

E-mail addresses: mvanwegberg@yahoo.com, M.vanWegberg@OS.unimaas.nl (M. van Wegberg).

$U R L$ : http://www.personeel.unimaas.nl/m.vanwegberg/.
} 


\section{Introduction}

An important aspect of several industries is the degree of compatibility between products. ${ }^{1}$ The choice of compatibility is important both for the suppliers and their (potential) customers. Compatibility between products tends to enhance the utility of a product for a user (more about the meaning of compatibility below). The advantages of compatibility for end users may increase the absolute size of market demand. Indirect evidence for a user preference for compatibility is that products with compatibility features tend to command a price premium (Gandal, 1995; Harhoff and Moch, 1997). Incompatibility on the other hand may reduce market demand. The announcement of a new incompatible format for optical media, the DIVX format, slowed demand for the newly established DVD format (Dranove and Gandal, 2000). A disadvantage of compatibility from the suppliers' perspective is that it eliminates one source of differentiation between their products. While not always true, a reduction of product differentiation is associated with more intense price competition and lower profits (Tirole, 1988, p. 295).

In many cases firms can choose whether they want their products to be compatible. There are several factors that influence their preferences for compatibility. Two of these factors are the absolute size of the market demand created by a new technology and the firm's share of the associated revenues (Shapiro and Varian, 1999, p. 198). An incompatible technology, based on a proprietary standard, may increase or safeguard the firm's appropriation of revenues. Incompatibility may be the price to pay if suppliers want to appropriate revenues from their technology development efforts. Compatible technologies, on the other hand may increase overall market demand. An innovator may decide to give up control over its technology in order to trade-off its share of total revenues for the total size of revenues.

Firms may have to choose between either increasing overall market demand or increasing their share of the revenues. A corollary of this insight is that firms with different sources of profits can differ in their preference for compatibility. Some suppliers in a market may well be active in multiple product markets. The direct effects of the compatibility choice for a technology in one market may have indirect consequences in other markets. As a result, the choice of compatibility may work out differently for a pure player, a firm that is active only in one product market, than for multi-market firms with interests in related markets. A pure player needs to recoup its technology efforts in the market directly affected, so it tends to focus on the appropriability of its investments. A multi-market firm can afford to focus on growing the market, knowing that it can recoup its investments in other markets that are positively affected by the growing market. When the market directly affected by a standard has spillovers on other markets, the market demand size motive when choosing a standards' regime may be more important than the appropriation motive.

\footnotetext{
${ }^{1}$ For academic studies of the compatibility choice, see the accessible textbook by Shapiro and Varian (1999), and the surveys by Katz and Shapiro (1994), Matutes and Regibeau (1996), and Farrell and Klemperer (2001).
} 
The paper first reviews the literature on compatibility choice. Next it works out a basic three-stage game theoretic model. The model explores the compatibility choice in a context with two product markets that can be connected by either a multimarket firm or an industry-wide alliance. It studies how a change in market scope may cause a strategic shift in a firm's compatibility choice. The interesting case of incompatible digital video formats, and the ultimate adoption of a compromise industry standard, the DVD, illustrates the issues in a real world context. A concluding section wraps up the paper.

\section{Factors that influence the compatibility choice}

Compatibility is a characteristic of products that need to interact with other products in order to create a performance for end users (Farrell and Saloner, 1986; Katz and Shapiro, 1986; Matutes and Regibeau, 1996). Compatibility raises the level and predictability of performance. If a product enables communication, such as a telephone, different products are called compatible if their users can communicate with each other. All users who use different, but compatible, products form a network. The size of the network of users increases the utility of the service (more people to communicate with), which represents a direct network externality (Katz and Shapiro, 1985, 1986).

Individual products can be parts of a system of interconnected products. In this context compatibility means that different products complement each other, that is, link to the same system. Users can mix any couple of complementary products (such as hardware and software) if these are compatible with one another (Matutes and Regibeau, 1988). Complementary systems can also lead to an indirect network externality, that is, sales of either compatible product benefit users of the other compatible product indirectly, by stimulating sales, investments, and improvements of the complementary product. Another indirect externality occurs if interchangeability of parts facilitates mass production when that leads to economies of scale (Farrell and Saloner, 1986). In short, if products are compatible, they enable a positive network externality to their users. Either directly or indirectly, compatibility makes it possible for given resources to enable a better performance for the end users.

The extent to which products in a market are compatible has important effects on end users and their product demand. Compatibility is likely to benefit the users (all else remaining equal) by enabling positive network externalities. In a dynamic context, however, the need for compatibility with established products (backward compatibility) may hold back new innovations (Davis et al., 2001). As an alternative to this excess inertia, there may also be excess momentum: consumers abandon existing technology, fearing that it will not be compatible with a recently announced innovation (Farrell and Saloner, 1986). Metcalfe and Miles (1994) distinguish between short-term and long-term effects of compatibility. The short-term effect of compatibility is to create order and reduce variety. It reduces variety for producers (fewer technologies to choose from) or consumers (by eliminating products that use other technologies than the one that became the standard). Standardization also, 
however, expands the market, which itself tends to arouse creativity and variation. Demand growth and large market size stimulate the development of compatible and complementary products.

Compatibility between products tends to be a choice for their suppliers. The compatibility choice they make may have large consequences for their performance. A market leader may prefer its product to be incompatible with a weaker rival, to prevent the latter from competing with it in more equal terms. From this argument Economides and Flyer (1998) derive the counter-intuitive result that the more important the network externality is, the less likely that firms will prefer compatibility between their products. When compatibility helps a firm's rivals, it may help them better compete with the focal firm, which may induce a firm from avoiding a compatibility setting coalition. The more intense product market competition is, the less likely that a firm will engage in a compatibility alliance with rivals (Bloch, 1995).

The effects of incompatibility can be mitigated by using an adapter to connect incompatible products. There are various kinds of adapter such as an interface, emulator, converter or gateway. The choice of compatibility can be unilateral, if one firm decides to build an adapter, or bilateral, if all suppliers have to accept the adapter. If a firm can build an adapter unilaterally, it is likely to be the small firm in a market (Katz and Shapiro, 1985). A small firm catches up on the greater network of the market leader by using an adapter. The market leader is likely to try to reject the adapter, as it prefers its weaker rivals to be incompatible. Creating an adapter makes two products partially compatible, which shows that the compatibility choice does not have to be a yes or no affair (De Palma et al., 1999). If a new technology is incompatible with the established technology, a converter between these technologies can both help and hurt the new technology (Choi, 1996a). The converter helps the new technology to benefit from the older technology's network, but it also prolongs the useful life of the older technology, as it now has a converter to the new technology.

Compatibility has various dynamic implications, which in turn influence the choice of compatibility. The choice of compatibility influences the evolution of prices. If their products are incompatible, each firm will try to generate the network externalities mentioned above (such as economies of scale) by fierce competition. Firms are more willing to compete for customers today, if they believe that these customers form a network (an installed base) that increases the utility of their product for future customers. The associated price-cutting may make this scenario more attractive to users than the case when firms agree up front on supplying compatible products (Katz and Shapiro, 1986). Compatibility may prevent a crippling price war ex ante (before a standard is established) to build up market share. Once the products are introduced in the market, however, compatibility may facilitate customer switching between their product and their rivals' products, thus increasing price competition ex post.

In line with an evolutionary approach such as by Metcalfe and Miles (1994), technological uncertainty tends to delay compatibility. By developing competing technologies, firms can experiment and choose different avenues of technological 
Table 1

Factors that tend to increase $(+)$ or decrease $(-)$ the preference for compatibility

\begin{tabular}{|c|c|c|}
\hline Factor & $\begin{array}{l}\text { Increase }(+) \text { or } \\
\text { decrease }(-) \\
\text { compatibility }\end{array}$ & Literature \\
\hline Network externality & - & $\begin{array}{l}\text { Economides and } \\
\text { Flyer (1998) }\end{array}$ \\
\hline $\begin{array}{l}\text { Intensity of product market competition reduces } \\
\text { incentives to collaborate on compatibility }\end{array}$ & - & Bloch (1995) \\
\hline $\begin{array}{l}\text { Technological uncertainty calls for experimentation } \\
\text { by competition between incompatible technologies }\end{array}$ & - & Choi (1996b) \\
\hline $\begin{array}{l}\text { R\&D competition with uncertain outcomes tends } \\
\text { to create winners and losers. Winners prefer } \\
\text { incompatibility }\end{array}$ & - & $\begin{array}{l}\text { Farrell and Katz } \\
\text { (1998) }\end{array}$ \\
\hline $\begin{array}{l}\text { If speeding up technological progress is costly, firms } \\
\text { prefer compatibility, to slow down the race }\end{array}$ & + & Kristiansen (1998) \\
\hline $\begin{array}{l}\text { Price cutting to sell incompatible products reduces } \\
\text { profits }\end{array}$ & + & $\begin{array}{l}\text { Katz and Shapiro } \\
\text { (1986) }\end{array}$ \\
\hline $\begin{array}{l}\text { Using an adapter to connect an old technology to a } \\
\text { new incompatible technology delays the adoption } \\
\text { of the new technology }\end{array}$ & + & Choi (1996a) \\
\hline $\begin{array}{l}\text { A supplier of an old technology may use an adapter to } \\
\text { a new incompatible technology to survive the } \\
\text { introduction of the latter }\end{array}$ & - & $\begin{array}{l}\text { Katz and Shapiro } \\
(1986)\end{array}$ \\
\hline $\begin{array}{l}\text { The more time consuming a negotiation process, the } \\
\text { more attractive a hybrid standard setting process }\end{array}$ & - & $\begin{array}{l}\text { Farrell and Saloner } \\
\text { (1988) }\end{array}$ \\
\hline $\begin{array}{l}\text { A high customer preference for product variety } \\
\text { benefits from standardization of technology and } \\
\text { components }\end{array}$ & + & $\begin{array}{l}\text { Metcalfe and Miles } \\
\text { (1994) }\end{array}$ \\
\hline
\end{tabular}

development (Choi, 1996b). The resulting learning process can help firms to select the technology to standardize on. An up-front decision to focus on compatibility with a particular technology reduces the scope of this experimentation, and may be harmful to customers in the longer term. An up-front decision for compatibility reduces the incentives to do $R \& D$ in order to create an installed base. As a result of lower levels of R\&D, compatibility slows down technological progress (Kristiansen, 1998). If speeding up technological progress raises the required levels of $R \& D$ strongly, the firms will prefer compatibility to slow down the technological race between them. When firms compete in $\mathrm{R} \& \mathrm{D}$, the uncertainties of $\mathrm{R} \& \mathrm{D}$ tend to lead to winners and losers. The winner is subsequently likely to prefer incompatibility, in order to avoid the loser to catch up (Farrell and Katz, 1998). Technological uncertainty, therefore, tends to reduce compatibility.

The process needed to establish compatibility is costly, which is another reason why incompatibility may occur. There are various ways to achieve compatibility. One way is to formulate a standard, a specification, such that products that satisfy the specification are compatible. A collective process to set a standard avoids incompatibility but may slow down the market introduction of an innovation. Farrell and Saloner (1988) show that failure to reach an agreement in a collective process 
delays adoption of a standard, compared with the case of uncoordinated choice of technology. They propose as the best approach a hybrid process, where firms engage in collective standard setting, while introducing heir technology unilaterally if negotiations take too long. A hybrid standard setting process increases the speed of market introduction, compared to a collective standard setting process. It also, however, increases the risk that impatient suppliers introduce incompatible products in the market. Table 1 summarizes this discussion about the factors that affect the compatibility choice.

\section{Spillover effects and the compatibility choice}

A factor not discussed above that may also affect the compatibility choice is the effect of compatibility on the demand side of other product markets. Different product markets can be linked on the demand side or on the supply side. If products are complementary, the demand levels of their respective markets are linked (Church and Gandal, 1996; Matutes and Regibeau, 1989). A supply side link occurs when there is an economy of scale or learning by doing effect in an input that the production processes for both markets share. This will lead to an economy of scope (Baumol et al., 1982; Teece, 1980). A shared brand name or reputation can lead to an (informational) economy of scope. It is also possible that one market's product is an input in either the production process or consumption process in the other market. The positions of these products in the value chains of suppliers and customers will determine the potential for synergies among the markets.

A merger or alliance may change the scope of products over which a firm maximizes its profits. This may cause a strategic shift. It changes the incentives the firm has in competing within each of these product markets. In particular, it may change the preference of the firm for the compatibility between products within one of its product markets. This is an additional route through which an extension of a firm's product scope can change competition within individual product markets (Wegberg and Witteloostuijn, 1992).

The effect of multi-market scope on the compatibility choice may explain the strategic shift associated with a cross-market merger or alliance. A change in the firm's scope is positive or synergetic, if the firm's overall profit interests correlate positively with market demand size in the focus market. If a firm has a synergistic expansion of scope, it tends to prefer a collectively agreed compatibility standard. Without a positive expansion of scope, a firm like a pure player will make the compatibility choice that maximizes its value within the market. It may prefer incompatibility in order to give up some potential market demand size for higher revenues.

\section{A model of compatibility choice and multi-market scope}

The model intends to explore the argument of the paper in a simple way, without trying to be descriptively realistic. There is a focus market A. The products in market 
A have a positive network externality on the demand side. The utility of the product A to each user increases in the number of users of compatible technologies. The suppliers play a three-stage game. They first choose the scope of the product markets to take into account in their compatibility choice. Next they choose whether to adopt compatibility. Next, they compete in the product market.

There are two suppliers in market A, firms 1 and 2. They compete in prices $p_{i}$ (Bertrand competition). Marginal costs are given and identical to $c$. Each firm sells one unique product $\mathrm{A}_{i}$ with a given standalone quality level $v_{i}(i=1,2)$. The quality levels are given and different, with firm 1 having the high quality product: $v_{1}>v_{2}$. These quality differences are assumed to be unrelated to marginal costs. An example where this tends to hold are information goods. Each firm realizes forthcoming demand, which determines its output level $q_{i}$. The fixed costs are given and equal between the firms at F. They include capital investments as well as research and development. Each firm maximizes gross profits, $\pi_{i}=\left(p_{i}-c\right) q_{i}(i=1,2)$.

Each potential end user buys either zero units or one unit. There is a positive direct network externality: the utility of the product increases in the number of fellow users. A buyer $(j)$ derives a net utility from one unit of product $\mathrm{A}_{i}$ of

$$
U_{j}=\alpha_{j} v_{i}+\beta q_{i}-p_{i} .
$$

The parameter $\alpha_{j}$ indicates the importance of the standalone quality to an individual user. The parameter $\beta$ indicates the value of the network size (the network externality). The unit sales level of each individual product, $q_{i}$, determines the size of the network if the products are incompatible. If the products are compatible, they have the same network, and the network size equals the total sales level in market A, called $Q$. This changes net utility in the case of compatibility into $U_{j}=\alpha_{j} v_{i}+\beta Q-p_{i}$.

The consumer chooses the product that gives the largest net consumer surplus, provided that it is positive, otherwise she chooses not to buy. The $\alpha_{j}$ are uniformly distributed over an interval $\left[\alpha_{\min }, \alpha_{\max }\right]$ with a density of $\gamma$, which implies that there are $\gamma\left(\alpha_{\max }-\alpha_{\min }\right)$ potential buyers. The number of actual buyers equals the total sales level, $Q$. Among the consumers with increasing $\alpha$ 's from $\alpha_{\min }$ to $\alpha_{\max }$, there are two critical consumers: the one who is indifferent between buying product 2 (the low quality product) and not buying (with $\alpha_{2}$ ), and the one who is indifferent between products 1 and 2 (with $\alpha_{1}$ ). Given these critical consumers (to be determined below), the unit sales of products 1 and 2 in market $\mathrm{A}$ are:

$$
\begin{aligned}
& q_{1}=\gamma\left[\alpha_{\max }-\alpha_{1}\right], \quad q_{2}=\gamma\left[\alpha_{1}-\alpha_{2}\right], \quad \text { and } \\
& Q=\gamma\left[\alpha_{\max }-\alpha_{2}\right], \text { with } \quad \alpha_{\min } \leqslant \alpha_{2} \leqslant \alpha_{1} \leqslant \alpha_{\max } .
\end{aligned}
$$

There is another market, market $\mathrm{B}$, whose product $\mathrm{B}$ is complementary to product $\mathrm{A}$ in a specific sense: the utility of product B is higher for customers who bought a product $\mathrm{A}$ than for those who did not. It does not matter here whether a customer bought $A_{1}$ or $A_{2}$, nor does it matter whether $A_{1}$ and $A_{2}$ are compatible. The products $\mathrm{A}$ and $\mathrm{B}$ are not compatible products, therefore, like computer hardware and software. Instead, think of market $\mathrm{A}$ as computers and market B as for media with 
information about computers. People who have a computer probably derive more utility from reading about this market.

Market A opens up before market B, which means that both suppliers and customers first decide about buying and selling in market $\mathrm{A}$, before they decide about market B. Only buyers in market A are willing to buy product B. The buyers in market $\mathrm{B}$ are homogeneous. Each individual buyer has a demand curve: $p_{\mathrm{B}}=a-b q_{\mathrm{B}}$. The inverse market demand function in market $\mathrm{B}$ is: $p_{\mathrm{B}}=a-(b / Q) q_{\mathrm{B}}$, where $Q$ is the number of buyers of product A. Market B is a monopoly. The monopolist's marginal production costs are zero. The market outcomes are: $q_{\mathrm{B}}=a Q / 2 b ; p_{\mathrm{B}}=a / 2 ; \pi_{\mathrm{B}}=a^{2} Q / 4 b ; C S=a^{2} Q / 8 b$, where CS is the total consumer surplus. The consumer surplus per individual buyer, $C S_{j}$, is $a^{2} / 8 b$. By defining $d=a^{2} / 4 b$, the outcomes can be restated. The profit level in market $\mathrm{B}$ is:

$$
\pi_{\mathrm{B}}=d Q
$$

Consumers are considered myopic, that is, when deciding about buying product A, they do not anticipate on the consumer surplus they would realize later if they buy product $\mathrm{B}$. They are not sophisticated enough to understand the ramifications of decisions in market $\mathrm{A}$ to market $\mathrm{B}$.

The model is explored by three cases, each of which represents a first stage choice made by the firms. Case 1 explores two single-market suppliers in market $\mathrm{A}$ and a third firm in market B. The single-market firms in market A may form an alliance to set compatibility between their products. Case 2 explores one single-market firm in market $\mathrm{A}$, and one multi-market firm active in markets $\mathrm{A}$ and $\mathrm{B}$. Case 3 explores an industry-wide pre-competitive alliance of three single-market firms (two in market A and one in market B) to choose compatibility. In each case, firms choose compatibility by comparing the outcomes when products in market $\mathrm{A}$ are compatible to when they are not. This is the second stage of the game. Given the scope and the compatibility choice, the firms in market A choose their prices. This is the third stage of the game.

Call $Q_{s c}$ the total output level of market A in case $s(=1,2,3)$ when products are compatible, and $Q_{s i}$, when they are incompatible. The difference that compatibility makes in market $\mathrm{A}$, is $\Delta Q_{s}=Q_{s c}-Q_{s i}$. The argument that compatibility increases demand implies the prediction that $\Delta Q_{s}>0$ for all three cases. The relevant profit level may include profits in market $\mathrm{B}$, depending on the scope of the firms. The joint compatibility bonus of the firms is the difference between total profits when products are compatible and total profits when they are not. The proposition is that in cases 2 and 3 compatibility raises profits (a positive compatibility bonus), while in case 1 , compatibility reduces profits (a negative bonus).

\subsection{Case 1: compatibility choice by single-market vendors}

Case 1 explores the compatibility choice when the suppliers in market A (firms 1 and 2) are independent from the supplier (firm 3) in market B. 


\subsubsection{Case 1A: compatible products}

Given a choice for compatibility, case $1 \mathrm{~A}$ explores pricing in the market. Consumer utility for the consumer who is indifferent between product 2 and not buying is

$$
\alpha_{2} v_{2}+\beta Q_{1 \mathrm{c}}-p_{2}=0 \text {. }
$$

The following equality identifies the consumer who is indifferent between products 1 and 2:

$$
\alpha_{1} v_{1}+\beta Q_{1 \mathrm{c}}-p_{1}=\alpha_{1} v_{2}+\beta Q_{1 \mathrm{c}}-p_{2} .
$$

Together with Eq. (2), where $Q_{1 \mathrm{c}}=\gamma\left[\alpha_{\max }-\alpha_{2}\right]$, his gives three equations in $\alpha_{1}, \alpha_{2}$, and $Q_{1 \mathrm{c}}$, that can be solved to give:

$$
\begin{aligned}
& \alpha_{1}=\left(p_{1}-p_{2}\right) /\left(v_{1}-v_{2}\right), \\
& \alpha_{2}=\left(p_{2}-\beta \gamma \alpha_{\max }\right) /\left(v_{2}-\beta \gamma\right), \\
& Q_{1 \mathrm{c}}=\gamma\left[\left(\alpha_{\max } v_{2}-p_{2}\right) /\left(v_{2}-\beta \gamma\right)\right] .
\end{aligned}
$$

The thresholds $\alpha_{1}$ and $\alpha_{2}$ are constrained to lie in the interval $\left[\alpha_{\min }, \alpha_{\max }\right]$. A positive value for $\alpha_{2}$ requires an assumption:

4.1.1.1. Assumption. $\beta_{\gamma}<v_{2}$. Substitute Eq. (6) in Eq. (2) to get the demand levels $q_{i}$. Given these price and sales levels, firms have the following levels of gross profits:

$$
\begin{aligned}
& \pi_{1}=\left(p_{1}-c\right) \gamma\left[\alpha_{\max }-\left(p_{1}-p_{2}\right) /\left(v_{1}-v_{2}\right)\right], \\
& \pi_{2}=\left(p_{2}-c\right) \gamma\left[\left(p_{1}-p_{2}\right) /\left(v_{1}-v_{2}\right)-\left(p_{2}-\beta \gamma \alpha_{\max }\right) /\left(v_{2}-\beta \gamma\right)\right] .
\end{aligned}
$$

Each firm chooses its price to optimize its gross profits, given the price of its rival. Applying this to the gross profits in Eq. (7) determines the equilibrium prices as:

$$
\begin{aligned}
& p_{1}=\left(3 c\left(v_{1}-\beta \gamma\right)+\left(2 v_{1}-\beta \gamma\right)\left(v_{1}-v_{2}\right) \alpha_{\max }\right) /\left(4 v_{1}-v_{2}-3 \beta \gamma\right), \\
& p_{2}=\left(c\left(2 v_{1}+v_{2}-3 \beta \gamma\right)+\left(v_{2}+\beta \gamma\right)\left(v_{1}-v_{2}\right) \alpha_{\max }\right) /\left(4 v_{1}-v_{2}-3 \beta \gamma\right) .
\end{aligned}
$$

Substitute the profit maximizing price levels in the demand levels to get the level of sales and profits, including the sum total profit level of firms 1 and 2, $\pi_{1 \mathrm{c}}$ :

$$
\begin{aligned}
q_{1}= & \gamma\left(c-2 v_{1} \alpha_{\max }+\alpha_{\max } \beta \gamma\right) /\left(-4 v_{1}+v_{2}+3 \beta \gamma\right), \\
q_{2}= & \left(\gamma\left(v_{1}-\beta \gamma\right)\left(\alpha_{\max }\left(v_{2}+\beta \gamma\right)-2 c\right)\right) /\left(\left(\beta \gamma-v_{2}\right)\left(v_{2}+3 \beta \gamma-4 v_{1}\right)\right), \\
\pi_{1}= & \left(v_{1}-v_{2}\right) \gamma\left(c-\left(2 v_{1}-\beta \gamma\right) \alpha_{\max }\right)^{2} /\left(v_{2}+3 \beta \gamma-4 v_{1}\right)^{2}, \\
\pi_{2}= & \left(v_{1}-v_{2}\right) \gamma\left(v_{1}-\beta \gamma\right)\left(-2 c+\alpha_{\max }\left(v_{2}+\beta \gamma\right)\right)^{2} \\
& /\left(\left(v_{2}-\beta \gamma\right)\left(v_{2}+3 \beta \gamma-4 v_{1}\right)^{2}\right) .
\end{aligned}
$$

These outcomes determine the total profits, $\pi_{1 \mathrm{c}}$, and total output level, $Q_{1 \mathrm{c}}$, realized when the products of the single-market suppliers in market A are compatible.

\subsubsection{Case 1B: incompatible products}

Case $1 \mathrm{~B}$ explores pricing when the suppliers in market $\mathrm{A}$ are single-market firms, and they have chosen their products to be incompatible. With incompatible product 
in market A, each product has its own network of end users, with a network size of $q_{i}$. The consumer identified by $\alpha_{2}$ is indifferent between product 2 and not buying:

$$
\alpha_{2} v_{2}+\beta q_{2}-p_{2}=0 .
$$

The consumer identified by $\alpha_{1}$ is indifferent between products 1 and 2 :

$$
U_{j}=\alpha_{1} v_{1}+\beta q_{1}-p_{1}=\alpha_{1} v_{2}+\beta q_{2}-p_{2} .
$$

With the expressions $q_{1}=\gamma\left[\alpha_{\max }-\alpha_{1}\right]$ and $q_{2}=\gamma\left[\alpha_{1}-\alpha_{2}\right]$ in Eq. (2), this gives four expressions in four variables $\left(\alpha_{1}, \alpha_{2}, q_{1}, q_{2}\right)$. For ease of presentation, we define $\Gamma=v_{1} v_{2}-v_{2}^{2}-v_{1} \beta \gamma-v_{2} \beta \gamma+\beta^{2} \gamma^{2}$. Solve the four equations to give:

$$
\begin{aligned}
& \alpha_{1}=-\frac{1}{\Gamma}\left(p_{2} v_{2}+\left(\alpha_{\max } \beta \gamma-p_{1}\right)\left(v_{2}-\beta \gamma\right)\right), \\
& \alpha_{2}=-\frac{1}{\Gamma}\left(p_{2}\left(-v_{1}+v_{2}+\beta \gamma\right)+\beta \gamma\left(p_{1}-\alpha_{\max } \beta \gamma\right)\right), \\
& q_{1}=\frac{\gamma}{\Gamma}\left(-v_{2}\left(p_{1}-p_{2}-\left(v_{1}-v_{2}\right) \alpha_{\max }\right)+\left(p_{1}-v_{1} \alpha_{\max }\right) \beta \gamma\right), \\
& q_{2}=\frac{\gamma}{\Gamma}\left(-p_{2} v_{1}+p_{1} v_{2}+\left(p_{2}-v_{2} \alpha_{\max }\right) \beta \gamma\right) .
\end{aligned}
$$

This gives demand levels written as functions of the prices. Anticipating consumers' demand levels, the firms choose their price levels to maximize their gross profits. Given the profit functions, the first order conditions of optimality can be derived. Reformulated, these conditions are the reaction curves of the prices. Together, they determine the profit maximizing prices:

$$
\begin{aligned}
& p_{1}=\frac{1}{2}\left(c+v_{1} \alpha_{\max }+\frac{v_{2}}{4 \Gamma+3 v_{2}^{2}}\left(c\left(2 v_{1}+v_{2}-2 \beta \gamma\right)+v_{2} \alpha_{\max }\left(-3 v_{1}+2 \beta \gamma\right)\right)\right), \\
& p_{2}=\frac{1}{2}\left(c+v_{2} \alpha_{\max }+\frac{v_{2}}{4 \Gamma+3 v_{2}^{2}}\left(-v_{2}\left(-3 c+\left(2 v_{1}+v_{2}\right) \alpha_{\max }\right)+2\left(v_{1} \alpha_{\max }-c\right) \beta \gamma\right)\right) .
\end{aligned}
$$

The second order conditions for optimality hold when, as in the previous case $1 \mathrm{~A}$, $v_{1}>v_{2}$ and $v_{2}-\beta \gamma>0$, as well as when $\gamma>0$. These prices lead to tedious expressions for the output and profit levels:

$$
\begin{aligned}
\pi_{1}= & \frac{\gamma\left(v_{2}-\beta \gamma\right)}{\Gamma\left(4 \Gamma+3 v_{2}^{2}\right)^{2}}\left(\left(v_{1}-v_{2}\right) v_{2}\left(-c+2 v_{1} \alpha_{\max }\right)+\left(c\left(2 v_{1}+v_{2}\right)\right.\right. \\
& \left.\left.+\left(-2 v_{1}^{2}-2 v_{1} v_{2}+v_{2}^{2}\right) \alpha_{\max }\right) \beta \gamma-2\left(c-v_{1} \alpha_{\max }\right) \beta^{2} \gamma^{2}\right)^{2}, \\
\pi_{2}= & \frac{\gamma\left(v_{1}-\beta \gamma\right)}{\Gamma\left(4 \Gamma+3 v_{2}^{2}\right)^{2}}\left(\left(v_{1}-v_{2}\right) v_{2}\left(2 c-v_{2} \alpha_{\max }\right)-\left(c\left(2 v_{1}+v_{2}\right)\right.\right. \\
& \left.\left.-v_{2}\left(v_{1}+2 v_{2}\right) \alpha_{\max }\right) \beta \gamma+2\left(c-v_{2} \alpha_{\max }\right) \beta^{2} \gamma^{2}\right)^{2},
\end{aligned}
$$




$$
\begin{aligned}
q_{1}= & \frac{\gamma\left(v_{2}-\beta \gamma\right)}{\Gamma\left(4 \Gamma+3 v_{2}^{2}\right)}\left(\left(v_{1}-v_{2}\right) v_{2}\left(-c+2 v_{1} \alpha_{\max }\right)+\left(c\left(2 v_{1}+v_{2}\right)\right.\right. \\
& \left.\left.+\left(-2 v_{1}^{2}-2 v_{1} v_{2}+v_{2}^{2}\right) \alpha_{\max }\right) \beta \gamma-2\left(c-v_{1} \alpha_{\max }\right) \beta^{2} \gamma^{2}\right), \\
q_{2}= & \frac{-\gamma\left(v_{1}-\beta \gamma\right)}{\Gamma\left(4 \Gamma+3 v_{2}^{2}\right)}\left(\left(v_{1}-v_{2}\right) v_{2}\left(2 c-v_{2} \alpha_{\max }\right)-\left(c\left(2 v_{1}+v_{2}\right)\right.\right. \\
& \left.\left.-v_{2}\left(v_{1}+2 v_{2}\right) \alpha_{\max }\right) \beta \gamma+2\left(c-v_{2} \alpha_{\max }\right) \beta^{2} \gamma^{2}\right) .
\end{aligned}
$$

Summing up these output and profit levels gives the total output level, $Q_{1 \mathrm{i}}$, and the total profit level, $\pi_{1 \mathrm{i}}$, for the case where the single-market firms in market A choose their products to be incompatible.

\subsection{Single-market firms and compatibility choice}

The comparison between cases $1 \mathrm{~A}$ and $1 \mathrm{~B}$ reveals the incentives that singlemarket firms have for compatibility. Rather than introducing complicated bargaining procedures between firms, the model assumes that firms prefer the outcome that offers the largest total profits. The Coase theorem (Milgrom and Roberts, 1992) suggests that firms bargain to an efficient (for them) outcome. How they do that is left outside of this model. It is possible that firms exchange side payments, that is, when going from compatible to incompatible products, if one firm would gain and the other would lose, the one that gains compensates the one that loses. Side payments can be made during compatibility bargaining, if firms also need to settle license fees among themselves for the technologies that together constitute the technology they standardize on. The DVD bargaining process to be discussed further on saw examples of this.

The joint compatibility bonus is the difference, $\pi_{1 \mathrm{c}}-\pi_{1 \mathrm{i}}$, between total profits in market A when products are compatible and total profits when they are not. An analytical solution from comparing the total profit levels in these two cases is hard to interpret (and lengthy to reproduce). An obvious analytical result is when $\beta=0$, when there is no network effect (see the utility function (1)): the profits and sales when products are compatible equal those of incompatible products.

Additional insights come from a numerical solution. The numerical solution assumes that $\alpha_{\min }=0, \alpha_{\max }=1.5, \gamma=1$, and $v_{2}=0.2$. For values of $\beta$ in the interval $[0.01,0.05]$ and $v_{1}$ in the interval $[0.4,1]$, the second order conditions for optimality and the other assumptions hold $\left(\beta \gamma<v_{2}<v_{1}, 0<\Gamma\right)$. The sales bonus is positive: compatibility increases sales for all levels of $\beta$ and $v_{1}$ simulated. By increasing the network of each product (from its own sales to total industry sales), compatibility increases consumer utility. Consumers who would not buy a product before, now enter market A. For low levels of the marginal cost (about less than 0.08), compatibility increases total profits in market A. For higher levels of marginal cost (about 0.12 or higher), compatibility decreases total profits (for all values of $\beta$ and $v_{1}$ simulated). Compatibility enhances the quality of products with the same network benefit. This makes the products better substitutes for each other. The result is more 
competition, lower prices, and higher sales. If marginal costs are very low, the low prices can still offer profits, hence compatibility is more profitable than incompatibility. For high levels of marginal costs, the low prices due to compatibility reduce profits; hence incompatibility is more profitable. The interesting case for this paper is when single-market firms will prefer incompatible products. Hence, we assume henceforth relatively high marginal costs $(c=0.3)$.

\subsection{Case 2: compatibility choice with a multi-market supplier}

The second case is where the low quality firm in market A, firm 2, acquires or merges with firm 3 in market $\mathrm{B}$. This may change the preferences for compatibility of their products in market $\mathrm{A}$. When the products in market $\mathrm{A}$ are compatible, the situation is similar to the case $1 \mathrm{~A}$ up to the profit functions in Eq. (8). Firm 2 includes in its overall profits its profits in market B (Eq. (3)): $\pi_{2}=\left(p_{2}-c\right) q_{2}+d Q$. The second part of the right hand side reflects the fact that for each customer in market A, firm 2 earns an additional profit of $d$ in market B. The two suppliers in market A will prefer compatibility if this raises their total profits, which amount to

$$
\pi_{2 \mathrm{c}, \mathrm{i}}=\left(p_{1}-c\right) q_{1}+\left(p_{2}-c\right) q_{2}+d\left(q_{1}+q_{2}\right)
$$

Given the choice about compatibility, the firms take their product market decisions in a similar way as in case $1 \mathrm{~A}$ or $1 \mathrm{~B}$. The equations are unreported here to avoid undue repetition of different, but similar, results. A numerical solution with $\alpha_{\min }=0, \alpha_{\max }=1.5, \gamma=1, v_{1}=0.4$, and $v_{2}=0.2$, shows that for values of $\beta$ in the interval $[0.01,0.05]$ and $d$ in the interval $[0,1]$, compatibility increases sales in market A.

The compatibility choice depends on how market B profitability, the factor $d$, influences the joint compatibility bonus, the relative profitability of compatible products. As Fig. 1 shows, $d$ tends to increase the compatibility bonus. For large enough $d$, the compatibility bonus is positive.

For cases with high enough $d$, the firms prefer compatibility in case 2 in cases where they would prefer incompatibility in case 1 (the situation of case 1 is akin to the situation $d=0$ in Fig. 1). Multi-market firms tend to favour compatibility over incompatibility, because they include in their considerations the feedback effect of sales in market A on sales in market B. One consequence of this result is that a multimarket merger between firms 2 and 3 induces firms 1 and 2 to establish a standard setting alliance in market $\mathrm{A}$ : the merger and alliance are complementary.

\subsection{Case 3: Compatibility choice by an industry-wide alliance}

In case 2, the merger or acquisition between firms 2 (in market A) and 3 (in market B) has the synergy effect that decision making in market A explicitly takes into account the effect on market B. A multi-market alliance between firms 1, 2 and 3 would have a similar effect. Firms 1 and 2 may choose compatibility if they take into account that this enhances profits in market B, even though it decreases them in market $\mathrm{A}$ (as case 1 showed). The alliance focuses on total profits in markets $\mathrm{A}$ and 


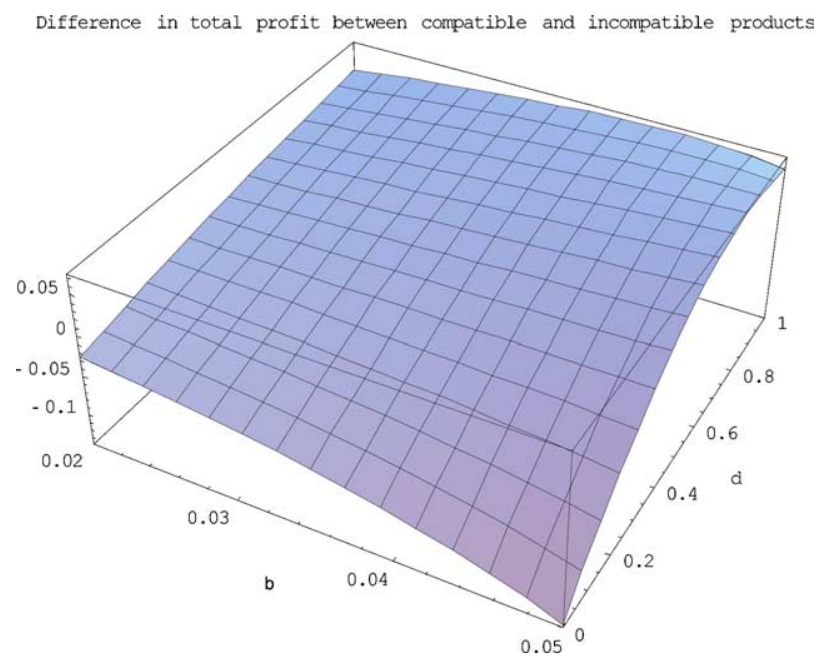

Fig. 1. Effects of network effect $(\beta)$ and demand spillover $(d)$ on compatibility bonus.

B, i.e., on $\left(p_{1}-c\right) q_{1}+\left(p_{2}-c\right) q_{2}+d\left(q_{1}+q_{2}\right)$. If compatibility would increase profits in markets A plus B taken together, there is a rationale for them to prefer compatibility. Firm 3 should, however, compensate for the loss of profits in market A. It can do that by sharing in the fixed costs of developing the technology in market A, or by licensing technology from the vendors in market A.

An alliance will not be permitted to adjust prices in market $A$ to raise demand in market B: that would be a cartel. An industry-wide alliance that combines firms 1,2 and 3 will exist only in the stage of the game where firms decide about compatibility. Once compatibility has been decided upon, the decision making by the firms in the two product markets is the same as in case 1 , where each firm in each market decides for itself. Their interaction is the same as in case 1, except that this time the criterion to choose compatibility is that total profits in market A plus B need to exceed profits when the products in market $\mathrm{A}$ are incompatible. The firms may therefore choose compatibility in situations where they would prefer incompatibility in case 1 . See Fig. 2.

Fig. 2 shows that the compatibility bonus can be both positive and negative, like in case 1 . The outcome when $d$ is zero is equal to the one of case 1 . Higher values of $d$ raise the compatibility bonus. For a large enough profitability of market B $(d)$, the compatibility bonus is positive. In these cases the three-firm alliance will choose compatibility when the firms 1 and 2 acting together in market A would not.

Fig. 3 shows the difference between the aggregate profits when three firms form an industry-wide alliance (case 3) versus when firms 2 and 3 merge (case 2).

Fig. 3 shows that the aggregate profits under an alliance are less than with a merger. While both the merger and the industry-wide alliance choose compatibility to maximize joint profits (Eq. (15)), given a choice for (in)compatibility, a merger leads to higher profits as it enables firm 2 to coordinate its pricing in market $A$ with 


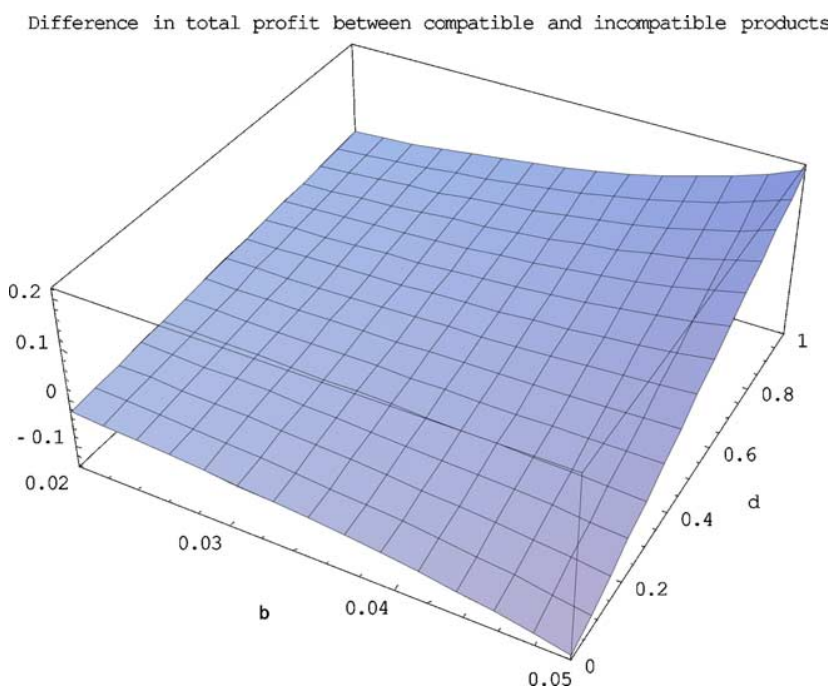

Fig. 2. The compatibility bonus from the perspective of a three-firm alliance.

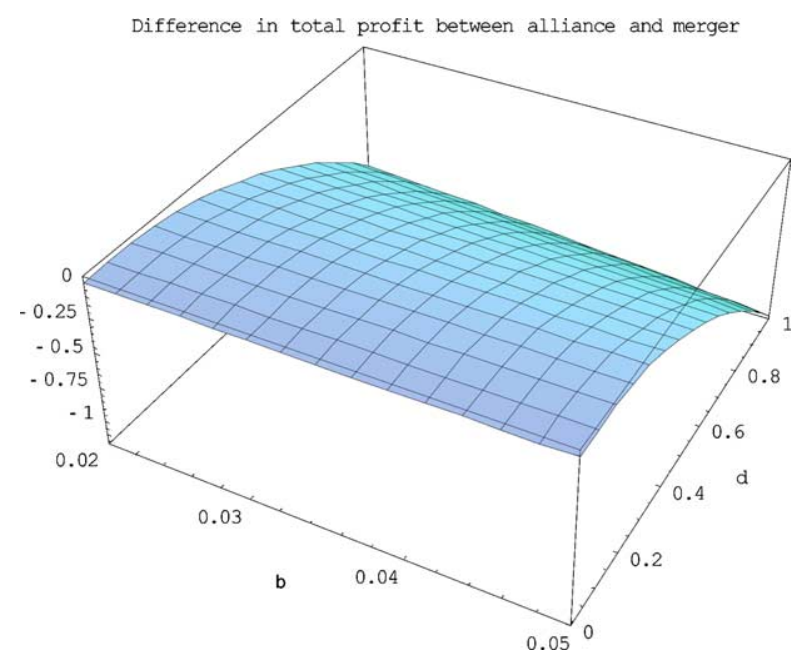

Fig. 3. Total profits of an industry-wide alliance minus those of a multi-market merger.

its interests in market B. If its feasible, firm 2 will prefer a multi-market merger to an industry-wide alliance.

\section{Intuition of the results}

Compatibility is a double-edged sword for the suppliers of market A: it raises consumer utility (the network externality effect) and thus the demand level, but also 
reduces the difference in consumer utility between the two products. The latter effect leads, given Bertrand price competition, to lower prices and profits for the suppliers. The lower prices in market A may, however, have a redeeming advantage if they stimulate demand in the related market B. The single-market suppliers in market A will, however, ignore this spillover effect.

There are two ways to convince the suppliers in market A to take this spillover effect into account. Firstly, the supplier in market B may merge with a supplier in market A. The combined firm is willing to accept lower prices in market A, due to compatibility, when this stimulates demand and profitability in market B. Secondly, an industry-wide alliance may help the supplier in market B to convince the suppliers in market A to accept compatibility. The gain for the supplier in market $\mathrm{B}$ is obvious. It will need side payments to the suppliers in market A to compensate them for their loss of profits. Mechanisms for this may be that the supplier of market B makes a predominantly financial contribution to the industry-wide alliances, while the suppliers of market A contribute in kind with their technological know how. The model indicates that a cross-market merger increases total industry profits compared to an industry-wide alliance. The merger creates a multi-market firm that lowers prices in market $\mathrm{A}$ in order to stimulate sales in market $\mathrm{B}$. A pro-competitive compatibility alliance has no such ability and is, therefore, less profitable.

\section{A case study}

The DVD format is an important standard that has become a major revenue source for film companies. The DVD case has attracted quite some academic interest (Dranove and Gandal, 2000; Lint and Pennings, 2003; Vercoulen and Wegberg, 1998). Other sources of information for this case are the business journals Business Week, The Economist, and the Wall Street Journal, the Dutch IT journal Automatisering Gids, and the websites of the DVD Forum ${ }^{2}$ and the electronics news site C:Net. ${ }^{3}$

The two companies that successfully introduced the CD media format in the 1980s, Philips and Sony, came out of this struggle with a lesson learned. By acquiring media interests they could leverage their power over media in the struggle to establish a new media format. In the late 1980s the three major consumer electronics companies Matsushita, Sony and Philips acquired film and music companies. They intended to use these interests to strong-arm the media industry in accepting a successor format to the CD: the format we now call the DVD. Table 2 shows the moves these three consumer electronics companies made.

Table 2 shows that Philips pioneered the strategy of integrating hardware and media businesses in one multi-market company. In the 1980s Philips acquired the

\footnotetext{
${ }^{2}$ http://www.dvdforum.org/forum.shtml.

${ }^{3} \mathrm{http}: / /$ www.news.com/?cnet.tkr.
} 
Table 2

Moves by consumer hardware firms in the media industry

\begin{tabular}{lllll}
\hline Year & Company & Move & Partners & Industry \\
\hline 1962 & Philips & Joint venture & Siemens; result is Polygram & Music \\
1987 & Philips & Acquisition & Polygram & Music \\
1988 & Sony & Acquisition & CBS Records & Music \\
1989 & Sony & Acquisition & Columbia Pictures & Film \\
1990 & Matsushita & Acquisition & MCA Universal & Film \\
1995 & Matsushita & Divestment & MCA Universal, to Seagram & Film \\
1998 & Philips & Divestment & Polygram, to Seagram & Music; film \\
\hline
\end{tabular}

majority interest in Polygram, and expanded the business from music to film. Sony and Matsushita followed suit. In the 1990s, however, Matsushita was the first to shed its media interest. Philips followed this move. Only Sony hangs on to the multimarket hardware/media scope. The pivotal event during the 1990s that triggered this development was the DVD standards battle (see Table 3).

Philips and Sony were well established in the media industry by the time they started their high density MMCD format group with the American company 3M. They had, in common with the result in cases 2 and 3 of the model above, preferred multi-market mergers to industry-wide alliances as a tool to establish a video disk format. In the following year of 1995, Toshiba announced a different, incompatible format, the Super Density disk. Toshiba did not have media interests of its own. It was successful nevertheless, by forming an alliance with media companies. Moreover,

Table 3

The DVD standards struggle

\begin{tabular}{|c|c|c|}
\hline Year & Event & Partners \\
\hline 1994 & High density Multimedia CD (MMCD) & Philips, Sony, 3M \\
\hline \multirow[t]{6}{*}{1995} & Super Density (SD) Disk & $\begin{array}{l}\text { Toshiba, Pioneer, Thomson, Mats- } \\
\text { ushita }\end{array}$ \\
\hline & Expansion of Super Density group & $\begin{array}{l}\text { Time Warner, Hitachi, JVC, Sam- } \\
\text { sung, Mitsubishi, MGM/United Ar- } \\
\text { tists, MCA }\end{array}$ \\
\hline & Expansion of MMCD group & $\begin{array}{l}\text { Mitsumi, Teac, Ricoh, Alps, Acer } \\
\text { Peripherals }\end{array}$ \\
\hline & Hollywood Digital Advisory group & $\begin{array}{l}\text { Hollywood film producers want to be } \\
\text { involved in standardization }\end{array}$ \\
\hline & $\begin{array}{l}\text { Joint statement calling for a single standard for } \\
\text { DVD }\end{array}$ & Apple, Compaq, HP, IBM, Microsoft \\
\hline & $\begin{array}{l}\text { DVD Forum is formed, a consortium to merge } \\
\text { the MMCD and SD alliances }\end{array}$ & $\begin{array}{l}\text { Hitachi, Matsushita, Mitsubishi, Pio- } \\
\text { neer, Philips, Sony, Thomson, Time } \\
\text { Warner, Toshiba, Victor }\end{array}$ \\
\hline \multirow[t]{2}{*}{1997} & $\begin{array}{l}\text { DVD Forum becomes an open membership } \\
\text { organization for digital optimal media stan- } \\
\text { dardization }\end{array}$ & $\begin{array}{l}\text { DVD Forum (with more than } 230 \\
\text { members as of Aug. 2003) }\end{array}$ \\
\hline & $\begin{array}{l}\text { Announcement of the DIVX format, } \\
\text { (partially) incompatible with DVD }\end{array}$ & Circuit City \\
\hline 1999 & DIVX support withdrawn from the market & Circuit City \\
\hline
\end{tabular}


its partner Matsushita brought with it its own media business, MCA. Lint and Pennings (2003) argue that Matsushita supported Toshiba as a deliberate ploy to delay the arrival of an industry standard for digital video, in order to protect its cash cow of the analog VHS videocassettes. Be that as it may, the integration of media businesses in the digital video standards battle helped to establish industry-wide compatibility around the DVD moniker.

The process of hammering out a compromise standard included the issue of how to divide the licensing revenues among the companies that got their technologies included in the compromise. It took a large part of 1995 to establish a licensing revenue sharing strategy. While bargaining may not have affected the preference for compatibility itself (as the model above assumed), it did put a pressure on the timetable of introducing the DVD.

This development revealed three weaknesses of the media acquisition strategies of the three majors. First, it might not help them when competing with each other. Secondly, a cross-industry alliance may do just as well in bringing media interests on board as a multi-market merger would. Toshiba clearly showed this: it had no media business of its own, but it was able to attract powerful media allies. In the absence of support from various media and consumer electronics firms, however, a new format cannot succeed. In the late 1990s the DIVX format came up as an incompatible alternative to the DVD (Dranove and Gandal, 2000). The rise and fall of the DIVX format demonstrated that lack of significant industry support could fatally hurt a format's adoption. Thirdly, acquiring media interests caused a strategic shift in the consumer electronics companies. The original plan appears to have been to use media interests to strengthen one's hand in the competition between incompatible new media formats. However, once media interests became part of the three consumer electronics majors, their interests shifted. The importance of the market adopting one's own format diminished. Instead, the importance increased of the media industry as a whole adopting a new standard.

The strategic shift induced by the acquisition strategies caused tensions within the consumer electronics conglomerates. Hardware divisions benefit the more their technology is included in a standard, because that is a basis for licensing revenues. A compromise standard that includes technologies from many other firms may hurt rather than help their cause. The media businesses, on the other hand, are mainly interested in having a standard. They may also have other interests in which kind of technologies are included in a standard. As a consequence, rifts revealed themselves within these conglomerates between the hardware and media businesses. The compatibility choice is only one such dividing factor. Illegal copying of music and film DVDs also divides the hardware and media businesses of Sony (C:net, 16 June 2002). Matsushita solved the associated problems by keeping MCA at a distance, which however defeated the purpose of acquiring MCA (Wall Street Journal Europe, 18-11-94).

This case illustrates that acquiring interests in a market with demand spillovers may change the strategy of a firm. It may increase its preference for compatibility, in order to benefit from positive spillovers on demand in the related markets. The firm may accept the strategic shift, and adjust its compatibility strategy accordingly. This 
happened when in late 1995, the major companies involved accepted the need to develop a compromise specification, the DVD. An alliance may also lead to such a strategic shift.

The model above points to the advantage of a merger above an alliance: a multimarket merger enables a firm to adjust prices, which also helps in exploiting spillovers between markets. Sony may well be an example of this cross-subsidization. Sony's large media interests are increasingly important as a source of profits. For example, in the fiscal year 2002, Sony lost \$62 million on its electronics sales, while it gained $\$ 152$ million in its music business (C:net, 16 June 2002). Partly, these results may indicate the multi-market firm's strategy of case 2 above: reduce prices in the hardware industry, so as to increase revenues in the media industry. Neither Philips nor Matsushita went this way. Philips' media business was too small to develop market power in the media market. Matsushita did not integrate the decision making of its hardware and media businesses enough to adapt its pricing strategies. Both companies may have learned that ad hoc alliances with media companies can be a better way to coordinate a compatibility choice.

\section{Conclusion}

The focus of this paper has been the strategic shift that when firms expand their product scope, this changes their preferences for compatibility of products in any particular product market. In the specific case explored here, the multi-market firm has a greater preference for compatibility than single-market vendors (pure players). The scope enhancing mergers in Information and Communication Technologies and e-commerce may thus increase the firms' preferences for compatibility and open standards. Since multi-market firms have different preferences with regard to standards than do single-market firms, firms may merge in our model, in order to change their preferences. A change in scope, either by a merger or by an alliance, causes a strategic shift with respect to compatibility choices. A cross-market merger may increase a preference for compatibility, which in turn may stimulate industry-wide alliances to adopt a compatibility standard. This indicates that in our model, at least, mergers and alliances are complementary rather than substitutes.

The analysis of the strategic shift may help understand the strategic upheavals of the three leading consumer electronics companies Matsushita, Sony, and Philips during the 1990s. They acquired media businesses to strengthen their hardware businesses that were involved in format wars that called for compatibility choices. As our model explains, the integration of media businesses changed their strategic thrusts with respect to the compatibility choice. Rather than pushing one's own incompatible format (as a single-market hardware firm would), the newly emerged conglomerates went for compatibility, even if this entailed significant compromises. Matsushita and Philips concluded from the emerging strategic shift that media caused too many conflicts within their organization. Sony instead fights on in order to explore the strategic potential that comes from being a multi-market conglomerate. 
Future work may relax the simplifying assumptions used in the model of this paper. Extensions are possible by explicitly analysing the bargaining process for compatibility, coalition formation choices, and the strategic use of pre-emptive moves in acquisition and compatibility games.

\section{References}

Baumol, W.J., Panzar, J.C., Willig, R.D., 1982. Contestable Markets and The Theory of Industry Structure. Harcourt Brace Jovanovich, New York.

Bloch, F., 1995. Endogenous structures of association in oligopolies. RAND Journal of Economics 26 (3), $537-556$.

Choi, J.P., 1996a. Do converters facilitate the transition to a new incompatible technology? A dynamic analysis of converters. International Journal of Industrial Organization 14 (6), 825-835.

Choi, J.P., 1996b. Standardization and experimentation: Ex ante vs. ex post standardization. European Journal of Political Economy 12, 273-290.

Church, J., Gandal, N., 1996. Strategic entry deterrence: complementary products as installed base. European Journal of Political Economy 12 (2), 331-354.

Davis, S.J., MacCrisken, J., Murphy, K.M., 2001. Economic perspectives on software design: PC operating systems and platforms (NBER Working Papers 8411). National Bureau of Economic Research, Inc.

De Palma, A., Leruth, L., Regibeau, P., 1999. Partial compatibility with network externalities and double purchases. Information Economics and Policy 11 (2), 209-227.

Dranove, D., Gandal, N., 2000. The DVD vs. DIVX standards war: empirical evidence of vaporware (Department of Economics, Working Paper Series E00-293). University of California, Berkeley.

Economides, N., Flyer, F., 1998. Equilibrium coalition structures in markets for network goods. Annales d'Economie et de Statistique (49/50), 361-380.

Farrell, J., Katz, M.L., 1998. The effects of antitrust and intellectual property law on compatibility and innovation. The Antitrust Bulletin, 609-650.

Farrell, J., Klemperer, P., 2001. Coordination and lock-in: competition with switching costs and network effects. Unpublished manuscript.

Farrell, J., Saloner, G., 1986. Installed base and compatibility: innovation, product preannouncements, and predation. American Economic Review 76 (5), 940-955.

Farrell, J., Saloner, G., 1988. Coordination through committees and markets. RAND Journal of Economics 19 (2), 235-252.

Gandal, N., 1995. Competing compatibility standards and network externalities in the PC software market. Review of Economics and Statistics 77 (4), 599-608.

Harhoff, D., Moch, D., 1997. Price indexes for PC database software and the value of code compatibility. Research Policy 26 (4-5), 509-520.

Katz, M.L., Shapiro, C., 1985. Network externalities, competition, and compatibility. American Economic Review 75 (3), 424-440.

Katz, M.L., Shapiro, C., 1986. Product compatibility choice in a market with technological progress. In: Morris, D.J., Sinclair, P.J.N., Slater, M.D.E., Vickers, J.S. (Eds.), Strategic Behaviour and Industrial Competition. Clarendon Press, Oxford, pp. 146-165.

Katz, M.L., Shapiro, C., 1994. Systems competition and network effects. Journal of Economic Perspectives 8 (2), 93-115.

Kristiansen, E.G., 1998. R\&D in the presence of network externalities: Timing and compatibility. RAND Journal of Economics 29 (3), 531-547.

Lint, O., Pennings, E., 2003. The recently chosen digital video standard: playing the game within the game. Technovation 23 (4), 297-306.

Matutes, C., Regibeau, P., 1988. "Mix and match": product compatibility without network externalities. RAND Journal of Economics 19 (2), 221-234. 
Matutes, C., Regibeau, P., 1989. Standardization across markets and entry. Journal of Industrial Economics 37 (4), 359-371.

Matutes, C., Regibeau, P., 1996. A selective review of the economics of standardization: entry deterrence, technological progress and international competition. European Journal of Political Economy 12, 183 209.

Metcalfe, J.S., Miles, I., 1994. Standards, selection and variety: an evolutionary approach. Information Economics and Policy 6, 243-268.

Milgrom, P., Roberts, J., 1992. Economics, Organization and Management. Prentice-Hall, Englewood Cliffs.

Shapiro, C., Varian, H.R., 1999. Information Rules: A Strategic Guide to the Network Economy. Harvard Business School Press, Boston, MA.

Teece, D.J., 1980. Economies of scope and the scope of the enterprise. Journal of Economic Behavior and Organization 1, 223-247.

Tirole, J., 1988. The Theory of Industrial Organization. The MIT Press, Cambridge, MA.

Vercoulen, F., Wegberg, M.v., 1998. Standard selection modes in dynamic, complex industries: creating hybrids between market selection and negotiated selection of standards (nib98006). University of Maastricht, NIBOR, Maastricht.

Wegberg, M.v., Witteloostuijn, A.v., 1992. Credible entry threats into contestable markets: a symmetric multimarket model of contestability. Economica 59 (236), 437-452. 